\title{
Myrmica vandeli Bondr. (Hymenoptera: Formicidae) in the Pieniny Mountains - the second record of this species for Poland
}

\author{
Wiesława CZECHOwsKa, Wojciech CZECHOwsKi and Alexander RADCHENKO \\ Laboratory of Social and Myrmecophilous Insects, Museum and Institute of Zoology PAS, Wilcza 64, \\ 00-679 Warszawa, Poland; e-mails: w.czechowska@robal.miiz.waw.pl,wcz@ robal.miiz.waw.pl, \\ agradchenko@hotmail.com
}

\begin{abstract}
The second record of Myrmica vandeli Bondr. for Poland is reported, and the current knowledge of its distribution is summarised. This poorly recorded ant species may be less rare than hitherto supposed. Its six colonies were found in the Pieniny Mts (southern Poland) in a marsh-meadow. Originally (in Czechowska 1976), they were erroneously determined as $M$. scabrinodis $\mathrm{Nyl}$.
\end{abstract}

Key words: ants, Myrmica vandeli, scabrinodis-group, fauna of Poland

\section{INTRODUCTION}

Myrmica vandeli Bondr. is a little known and poorly recorded ant species of the scabrinodis-complex (sensu Radchenko 1994 and Radchenko \& Elmes 2004). Described from France (Bondroit 1920), so far it was reported from a few wide-spread sites in Europe, from the British Isles to Romania and Yugoslavia (Kutter 1977, Elmes \& Thomas 1985, Seifert 1988, 1996, Markó 1999, Markó et al. 2004, Schlick-Steiner \& Steiner 2000, Elmes et al. 2003). The record from Turkish Thrace (Agosti \& Collingwood 1987) is based on a misidentification (AR, material examined). Recently M. vandeli was reported from Poland (Mt Otrosz, KrakowskoWieluńska Upland; Radchenko et al. 2003) (Fig. 1).

This species inhabits warm, humid places, being particularly abundant in marshes and bogs in the southern foothills of the Alps. As a rule, it co-occurs in the habitats with M. scabrinodis Nyl., that is, on the one hand, its ecological competitor, and on the other hand, the host of its temporary social parasitism. M. vandeli shows some "socially parasitic" features, such as reduced spurs and hairy body (see Elmes et al. 2003). Several times it was noticed living in mixed colonies with $M$. scabrinodis workers, which suggests $M$. vandeli to be (at least facultatively) a temporary social parasite of that species, particularly on marginal parts of the species range (Radchenko \& Elmes 2003).

M. vandeli might be just a poorly recorded species and may be not so rare as hitherto supposed. Probably, it has usually been erroneously determined as one of the related species, especially $M$. scabrinodis (as shown below). For the characteristic morphological features of the species and a key for separating it from their closest relatives see Radchenko et al. (2003).

\section{MYRMICA VANDELI IN THE PIENINY MOUNTAINS}

The Pieniny Mts (49 $24^{\prime}$ N, $20^{\circ} 24^{\prime}$ E; see Fig. 1) have a unique position in Polish faunistics. Built mainly of limestone, they are warm and relatively dry. Due to the geological and climatic separateness from surroundings, and therefore also its floristic and faunistic separateness (see e.g. Pancer-Kotejowa \& Zarzycki 1976, Kostrakiewicz 1982), this small mountain range (ca. $40 \mathrm{~km}^{2}$ ) is a peculiarity of nature on the European scale. In respect of the myrmecofauna, it is 
the richest of all Polish geographic regions; to date, as many as 63 ant species have been recorded there (Czechowski et al. 2002).

Myrmecofauna of the Pieniny Mts as a composite unity (i.e. besides fragmentary reports) were studied twice: qualitatively in the late 1940s (Koehler 1951) and qualitativequantitatively in the early 1970s (Czechowska 1976). One of taxonomic problems that arose during the latter studies concerned diagnosis of some Myrmica nest samples collected in a euthrophic marsh-meadow (Valeriano-Caricetum flavae). Finally the author defined them as M. scabrinodis, describing however their morphological deviation from more or less typical another local forms, and those occurring in dry biotopes, i.e. in the thermophilous meadow (Anthylli-Trifolietum), the herb meadow (association with Veratrum lobelianum Bernh. and Laserpitium latifolium L.) and the dry pasture (association with Salvia verticillata L.) (Czechowska 1976; for phytosociological characteristics of the biotope see Panzer-Kotejowa and Zarzycki 1976).

The recent findings of $M$. vandeli in Poland (Radchenko et al. 2003) and in Bulgaria (Stankiewicz \& Antonova, in prep.) in wet meadows inspired us to inspect the voucher specimens of «M. scabrinodis» sampled during the study under discussion, kept in the Museum and Institute of Zoology, PAS in Warsaw. As was to be expected, the questionable samples that had been collected in the Pieniny Mts upwards of 30 years ago appeared to represent $M$. vandeli - the $64^{\text {th }}$ ant species recorded from this region. (The total number of outdoor ant species found in Poland is now 96; see Radchenko et al. 2004).

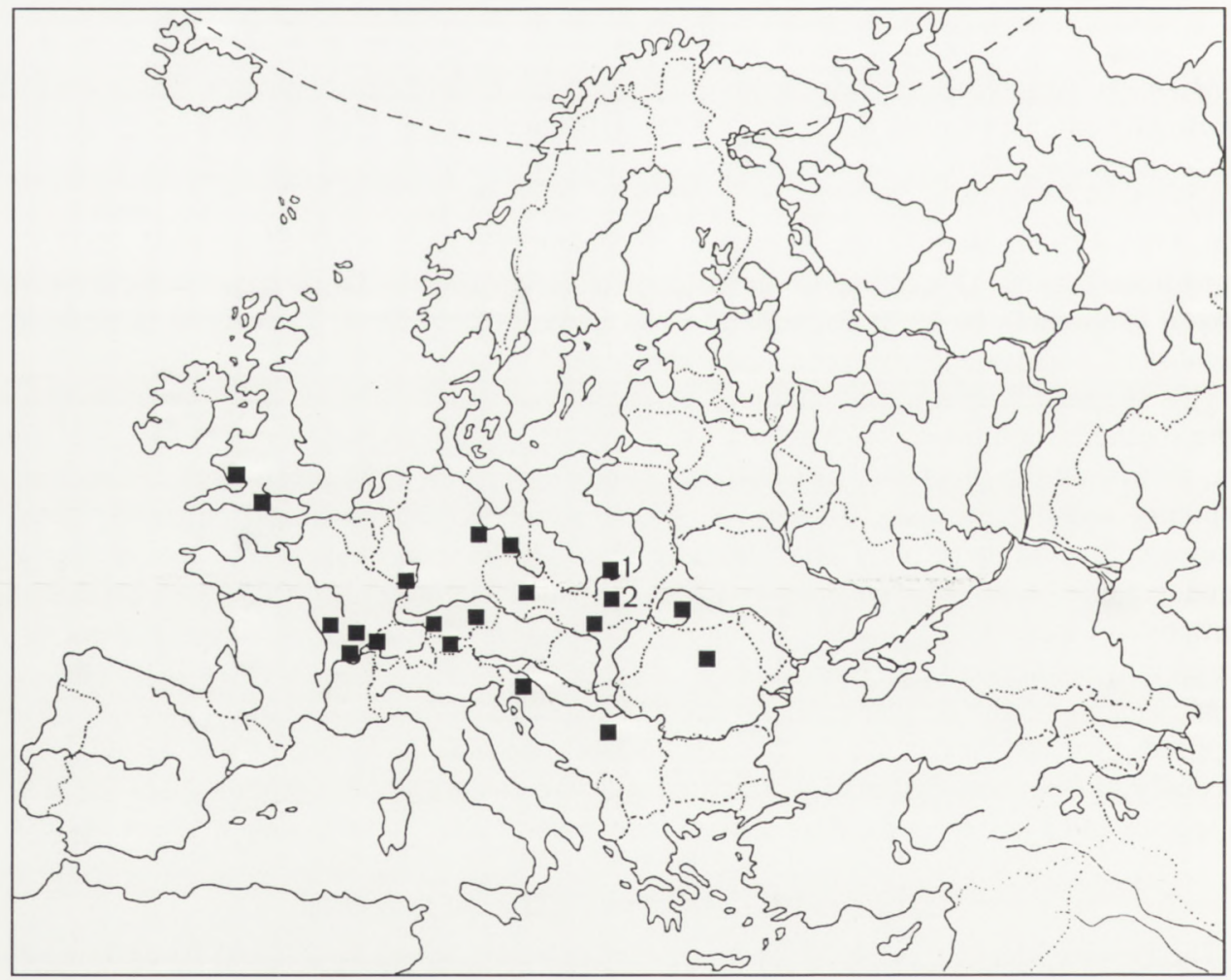

Fig. 1. Known localities of Myrmica vandeli in Europe; sites in Poland are numbered: 1 - Mt. Otrosz (KrakowskoWieluńska Upland (according to Radchenkoet al. 2003), 2 - Pieniny Mts, a new site. 
All these $M$. vandeli samples originated from the same biotope and locality: a euthrophic marsh-meadow on a gentle NE slope at the mouth of the Ociemny Stream to the river Dunajec near Krościenko [UTM DV67] at about $430 \mathrm{~m}$ a.s.l. Soil was peaty-gley, very wet, saturated with oozing water. Sedges, Carex davalliana Sm., C. rostrata Stokes, C. panicea L. and others, dominated the vegetation. Places between sedge tufts, permanently covered by water, overgrew, among others, Valeriana simplicifolia (Rchb.) Kab., Eriophorum latifolium Hoppe, Pinguicicula vulgaris L., Orchis latifolia L., Lysimachia vulgaris L., and mosses (see PancerKotejowa and Zarzycki 1976). Myrmica nests, with mounds of fine plant remnants, were situated in big tufts of sedges.

The local ant community consisted of three ant species: $M$. rubra (L.) (=M. laevinodis Nyl. in Czechowska 1976), M. scabrinodis and M. vandeli. Densities of their nests were very high: $0.27 / \mathrm{m}^{2}(38 \%), 0.33 / \mathrm{m}^{2}(48 \%)$ and $0.10 / \mathrm{m}^{2}(14 \%)$ respectively $\left(0.70 / \mathrm{m}^{2}\right.$ together). For comparison: $M$. scabrinodis nest densities were $0.04 / \mathrm{m}^{2}$ in the thermophilous meadow, $0.04 / \mathrm{m}^{2}$ in the herb meadow and $0.02 / \mathrm{m}^{2}$ in the dry pasture, and the total nest density of all Myrmica species there were $0.044,0.06$ and 0.26 respectively (Czechowska 1976). Three colonies of $M$. vandeli were found during these quantitative investigations, which in the marsh-meadow studied were made on 11.08.1973. Three more M. vandeli colonies were sampled in the same meadow as the result of qualitative searches on 30.07.1974. Analyses of all of the nest samples of $M$. scabrinodis and $M$. vandeli collected in the Pieniny Mts did not show the existence of the mixed colonies of these species, found at some other sites (see Elmes et al. 2003, Radchenko \& Elmes 2003).

\section{ACKNOWLEDGEMENTS}

The authors thank two referees, Graham Elmes and Bram Mabelis, for reviewing and improving the manuscript.

\section{REFERENCES}

Agosti D. \& Collingwood C. A. 1987. A provisional list of the Balkan ants (Hym. Formicidae) and a key to the worker caste. 1. Synonymic list. Mitt. Schweiz. Ent. Ges. 60: 51-62.

BONDROIT J. 1920. Notes diverses sur les fourmis d'Europe. Ann. Soc. Entomol. Belg. 59 (1919): 143-158.

CzechowsKa W. 1976. Myrmekofauna Pienińskiego Parku Narodowego (Hymenoptera, Formicoidea). Fragm. Faun. 21: 115-144.

Czechowski W., Radchenko A. \& CzechowsKa W. 2002. The ants (Hymenoptera, Formicidae). Museum and Institute of Zoology, PAS, Warszawa, $200+1 \mathrm{pp}$.

Elmes G. W., RAdChenko A. G. \& Thomas J. A. 2003. First records of Myrmica vandeli (Hymenoptera, Formicidae) for Britain. Brit. J. Ent. Nat. Hist. 16: 145-152.

Elmes G. W. \& ThOMAS J. A. 1985. Morphometrics as a tool in identification: a case study of Myrmica from France (Hymenoptera, Formicidae). Act. Coll. Insectes Soc. 2: 97-108.

Elmes G. W., Thomas J. A., Wardlaw J. C., Hochberg M., Clarke R. T. \& Simcox D. J. 1998. The ecology of Myrmica ants in relation to the conservation of Maculinea butterflies. J. Insect Conserv. 2: 67-78.

Kostrakiewicz L. 1982. Zarys fizjografii Pienin. Klimat. In: Przyroda Pienin w obliczu zmian. Studia Naturae, B, 30 : 53-69.

KUTTER H. 1977. Hymenoptera, Formicidae. Insecta Helvetica. Fauna. 6. Zürich, 298 pp.

MARKÓ B. 1999. New ant taxa (Hymenoptera: Formicidae) in the Romanian fauna. Entomol. Rom. 4: 95-98.

MARKó B., KISS K. \& GALLÉ L. 2004. Mosaic structure of ant communities (Hymenoptera: Formicidae) in Eastern Carpathian marshes: regional versus local scales. Acta Zool. Acad. Sci. Hung. 50 (in press).

PANCER-KOTEJOWA E. \& ZARZYCKI K. 1976. Zarys fizjografii i stosunków geobotanicznych Pienin oraz charakterystyka wybranych biotopów. Fragm. Faun. 21: 21-49.

RADCHENKO A. G. 1994. Taxonomic structure of the genus Myrmica (Hymenoptera, Formicidae) of Eurasia. Communication 1. Zool. Zh. 73: 39-51 [in Russian; English translation: Entomol. Rev. 1995, 74: 91-106].

Radchenko A., Czechowska W. \& Czechowski W. 2004. Mrówki - Formicidae. Klucze do oznaczania owadów Polski. Polskie Towarzystwo Entomologiczne, Toruń (in press).

RAdCHENKo A. \& Elmes G. W. 2003. A taxonomic revision of the socially parasitic Myrmica ants (Hymenoptera: Formicidae) of the Palaearctic region. Ann. Zool. 53: 217-243. 
RADCHENKo A. \& ElmES G. W. 2004. Taxonomic notes on the scabrinodis-group of Myrmica species (Hymenoptera, Formicidae) living in eastern Europe and western Asia, with a description of a species from Tien Shan. Trudy Russskogo Entomologicheskogo Obshchestva 75: 222-233.

Radchenko A., Elmes G. W., CZechowska W., Stankiewicz A., Czechowski W. \& Sielezniew M. 2003. First records of Myrmica vandeli Bondroit and $M$. tulinae Elmes, Radchenko et Aktaç (Hymenoptera: Formicidae) for Poland, with a key for the scabrinodis- and sabuleti-complexes. Fragm. Faun. 46: 47-57.

SCHLICK-STEINER, B. C. \& STEINER F. M. 2000. Die Moorbewohnerin Myrmica vandeli Bondroit 1920: Erstnachweis für Ostösterreich und Einsatz im Naturschutz. Ameisensch. Aktuell 14: 113-115.

SEIFERT B. 1988. A taxonomic revision of the Myrmica species of Europe, Asia Minor, and Caucasia (Hymenoptera, Formicidae). Abh. Ber. Naturkundemus Görlitz. 62: 1-75.

SEIFERT B. 1996. Ameisen: beobachten, bestimmen. Naturbuch Verlag, Augsburg, 352 pp.

\section{STRESZCZENIE}

[Tytul: Myrmica vandeli Bondr. (Hymenoptera: Formicidae) w Pieninach - drugie doniesienie o występowaniu tego gatunku w Polsce]

Rewizja materiałów dowodowych, stanowiących podstawę dawnego opracowania myrmekofauny Pienin (Czechowska 1976), wykazała obecność nowego dla tego regionu gatunku mrówki, Myrmica vandeli Bondr., a zarazem jego drugie stanowisko w Polsce (zob. Radchenko et al. 2003). W Pieninach M. vandeli występowała na młace (Valeriano-Caricetum flavae) w pobliżu Krościenka nad Dunajcem, gdzie w latach 1973 i 1974 znaleziono sześć jej gniazd. Pierwotnie gatunek ten został utożsamiony (choć nie bez wątpliwości) z licznie występującą w Pieninach (m.in. współwystępującą z $M$. vandeli na tej samej młace) $M$. scabrinodis Nyl. (zob. Czechowska 1976). Informacja ta wydłuża listę myrmekofauny Pienin najzasobniejszego w gatunki mrówek regionu Polski (zob. Czechowski et al. 2002) - do 64 gatunków. 